Paper published in Forum for Development Studies, 16 November 2021

To cite this article: Gibrán Cruz-Martinez (2021): Universal social pensions are unaffordable ... Not! Testing the unaffordability hypothesis in Latin America and the Caribbean. Forum for Development Studies. https://doi.org/10.1080/08039410.2021.1998212

\title{
Universal social pensions are unaffordable ... Not! Testing the unaffordability hypothesis in Latin America and the Caribbean
}

\author{
Gibrán Cruz-Martínez \\ Complutense University of Madrid
}

gicruz@ucm.es

\begin{abstract}
Is universal social assistance unaffordable? Targeting social policy has been praised as a magic solution to select the "deserving poor" and efficiently use the scarce resources in the Global South. The paper tests the unaffordability hypothesis using five counterfactual analyses based on expenditure redirection (military expenditure, energy subsidies, and the potential illegal/odious external debt servicing) and increasing tax revenues (income and trade tax) in up to thirty-three countries. The paper shows the revenue-generating potential of taxes and reprioritising expenditures from unproductive to productive areas to finance -totally or partly- basic universal social pensions in a large part of the region. Therefore, dispelling the unaffordability myth.
\end{abstract}

Keywords: social policy; targeting; welfare state; social protection; older age; cash transfers; social assistance

\section{Introduction}

A large part of the Latin American and Caribbean region has implemented non-contributory pensions social pensions- in their social policy menu. Social pensions provide income support for retirement for the older-age population, creating a first pillar - a basic social protection floor - for those above the age eligibility and who meets the different eligibility requirements (e.g., income, residence, legal status, citizenship). 
Targeting social policy has been praised as a magic solution to select the "deserving poor" and use the scarce resources of governments in the Global South as efficient as possible. The World Bank (2012) argues for efficient and effective social protection programs and links the affordability criteria to a "well-targeted" condition. Almost three decades ago, the World Bank (1994) praised universal pensions; however, the Bank and other financial institutions have tended to ignore universal pensions (Willmore, 2007).

On the other hand, universalism has been portrayed as unaffordable for being too expensive (Laenen \& Gugusgvili, 2020). Even though international financial institutions and most governments worldwide continue recommending and using targeting in social protection programs (Heimo, 2019), its praised efficiency has been questioned in multiple publications (Dethier, Pestieau, \& Ali, 2010; S. Devereux et al., 2015; Kidd \& Wylde, 2011; Li \& Walker, 2016; Sandberg, 2016). Moreover, the literature has highlighted options to expand fiscal space and generate resources for universal social protection (Ortiz et al., 2017b; Durán-Valverde \& Pacheco, 2012).

This paper's primary purpose is to test the unaffordability assumption of social assistance in the Global South by examining several options for potentially creating new sources of revenue in Latin America and the Caribbean. Twenty-eight countries in the region have established non-contributory pensions - also known as social pensions - in the social protection menu to secure a basic social protection floor of income support for the older-age population. However, no country has extended coverage to every older-age individual (Cruz-Martínez, 2020). The literature argues that Bolivia's 'Renta Dignidad', Guyana's Old Age Pension, and Suriname's 'Algemene Oudedags Voorzieningsfonds' are universal social pensions; however, they incorporate citizenship and residency eligibility requirements which exclude multiple categories of migrants (Cruz-Martínez, 2016; ECLAC, 2016; HelpAge International, 2015; Wolff, 2013).

The debate over the sustainability of social expenditure and the unaffordability of universal benefits -seen as "too expensive"- rests on many assumptions (Jouste \& Rattenhuber, 2018). Recent research has dealt with the unaffordability debate of universal social protection, particularly with social pensions (Guven \& Leite, 2016; Jouste \& Rattenhuber, 2018), healthcare (PAHO, 2020; Verguet et al. 2021) or basic income (Greenstein, 2019). Among the arguments used to support the unaffordability hypothesis, we can highlight the following: challenging to sustain in low- and high-income settings, less cost-effective than targeted policies, or challenging to achieve with an adequate pension level (Guven \& Leite, 2016; Gugusgvili \& Hisrch, 2014; Cowan, 2017).

The literature proposes several proposals to help implement universal programs. For example, locally-led priority setting to select the most appropriate mix of services within resource-constrained settings (Verguet et al. 2021), delivering the message that social protection is not a handout and does not disincentive economic growth (Seekings, 2017), allocating gains from economic growth to expand universal coverage (Hailu et al., 2021), among others. However, according to the ILO (2015), the core challenge for financing universal social protection remains to secure the necessary fiscal space.

Social protection in the region faces several challenges that threaten its affordability and sustainability, thus the relevance of the (un)affordability debate (Angell \& Graham, 2009; Barrientos \& Santibañez, 2009; Betranou, Casalí, \& Velasco, 2019). The first challenge relates to raising sufficient government revenues to finance social protection. Can countries in the Global South fund universal social assistance? The literature has dealt with economic (Ortiz et al. 2017a) and political (Seekings, 2017) affordability. In this paper, we consider the economic side. "Financing is a key constraint on the development of social protection" (Barrientos, 2007:11). Therefore, economic constraints of countries with under-institutionalised or inadequate tax systems severely limit the ability of the government to mobilise resources for welfare. In Latin America and the Caribbean, a regressive tax system and a limited tax burden curb the financing capacity to expand social protection.

Besides the institutional tax-related constraints, we must also consider the reality faced by the region due to their position in the global economy and the reforms in the last quarter of the 20th century. The high level of dependence on commodities and trade with centre economies limits the governments' sources of revenue (especially during the economic crisis) to fund social protection programs or any other social service (Cardoso \& Faletto, 1998; Prebisch, 1986). After the 1980s debt crises, the so-called structural adjustments during the neoliberal era imposed austerity measures and fiscal constraints across the region. These reforms were supposed to reduce the "distortionary" effects of taxes and government intervention. By lowering tax revenues and "starving the beast", the structural adjustments arbitrarily compromised the capacity of governments to raise revenues (Mkandawire, 2005). For example, revenues (excluding grants) are considerably lower in Latin America and the Caribbean (24\% in 2019) than in the European Union (36\% in 2019) and very close to sub-Saharan Africa (22,9\% in 2017) (World Bank, 2020). Although tax revenues as a percentage of GDP increased in the first decade of the 21st century, "indirect taxes on goods 
and services, which affect the entire population regardless of income level, constitute a disproportionate share of total tax income." (Arnson et al., 2012) Moreover, tax reforms in the last quarter of the 20th century increased the reliance on indirect taxes making the fiscal system more regressive (Mahon, 2012).

Second, the world population is ageing. During the last five decades, adults above 60 years of age in the world have more than a fourth-fold, and in Latin America and the Caribbean, the older-age population has sevenfold (UNPD, 2019). Also, the dependency burden of the working-age population has increased. The dependency ratio has reduced from 89.9 in 1966 to 74 in 1986, 56 in 2006, and 49.1 in 2020 (World Bank, 2020). This means that nowadays, there is one dependent for every two working-age adults. The increased level of dependency adds pressure to the economic sustainability of the welfare programs.

Third, even though there has been an increase in the coverage rate of pensions, there is still a long road ahead for universal coverage (Migdalia, Ordoñez, \& Valencia, 2018; Sojo, 2017; Cruz-Martínez et al., 2021). The share of people in Latin America and the Caribbean aged 65 or older who receive a retirement pension is - on average - 38 per cent (CEDLAS \& World Bank, 2016). Due to the current low level of social insurance coverage, social pensions secure a basic protection floor for every older-age individual. There is some optimism for the future as the share of salaried workers with the right to pensions when retired in the region is - on average - 57 per cent (CEDLAS \& World Bank, 2020).

Fiscal and social policy literature guides the investigation. The paper conducts five counterfactual analyses based on expenditure redirection (military expenditure, energy subsidies and debt payments) and increasing tax revenues (income and trade tax) to test the unaffordability assumption of universal social pensions. With only five of the multiple alternatives to fund universal social protection in the region, the paper contributes to debunking the unaffordability myth of universal social assistance. The paper uses social pensions to test the unaffordability assumption, but any social assistance, insurance or benefits-in-kind could have been used. The topic is clearly relevant from a policy perspective and timely due to renewed debates about universal income schemes (e.g., basic income) as a response to the vastly negative economic consequences of the COVID-19 pandemic.

After this introduction, the following sections present the analytical and conceptual framework of the article; show the main results obtained in the five counterfactual analyses proposed; discuss the results; and, finally, refer to the main conclusions, limitations of the study and the future of this line of research.

\section{Creating fiscal space and funding social pensions}

The concepts of fiscal space, social pension and universalism need to be addressed before proceeding with the counterfactual reasoning and the fiscal space creation analyses.

Fiscal space is defined as "a room in a government's budget that allows it to provide resources for the desired purpose without jeopardising the sustainability of its financial position or the stability of the economy" (Heller, 2005). Therefore, the existence of fiscal space implies that governments can increase social expenditure and social welfare programmes without "endangering market access and putting debt sustainability at risk." (Syed et al., 2016, p. 6). Researchers have been able to identify multiple sources of fiscal space to finance social protection (Hujo \& McClanahan, 2009; Koreh, 2017; Ortiz, Cummins, \& Karunanethy, 2015).

The primary sources are domestic tax revenues (e.g., income tax, excise tax), expenditure redirection, restructuring public debt and interest payments, broadening the tax base, enhancing expenditure efficiency, external financing, eliminating illicit financial flows and tax havens, and increasing the economy's productive capacity. This paper focuses on the first three sources because of their high potential for fiscal space creation and cross-country data availability.

All these fiscal space creation strategies are supported by policy statements of the United Nations and International Financial Institutions (Ortiz et al., 2017a). Ortiz et al. (2017a) provide some examples: Thailand and Costa have relocated military expenditure for universal health, Bolivia and Mongolia are financing social pensions and child benefits with taxes from mining and gas, Egypt reviewed expenditure priorities to promote social justice.

As Figure 1 shows, social pensions are among the various social protection programmes in the social policy menu. Social pensions are cash-transfer programs implemented to level up individuals to a societal minimum (i.e., social protection floor). The main difference with the social insurance programmes is the absence of a direct contribution to a general fund as an eligibility requirement to become a beneficiary. Also, social insurance programs follow a different logic (i.e., consumption smoothing). 
Figure 1: The Social Policy Menu

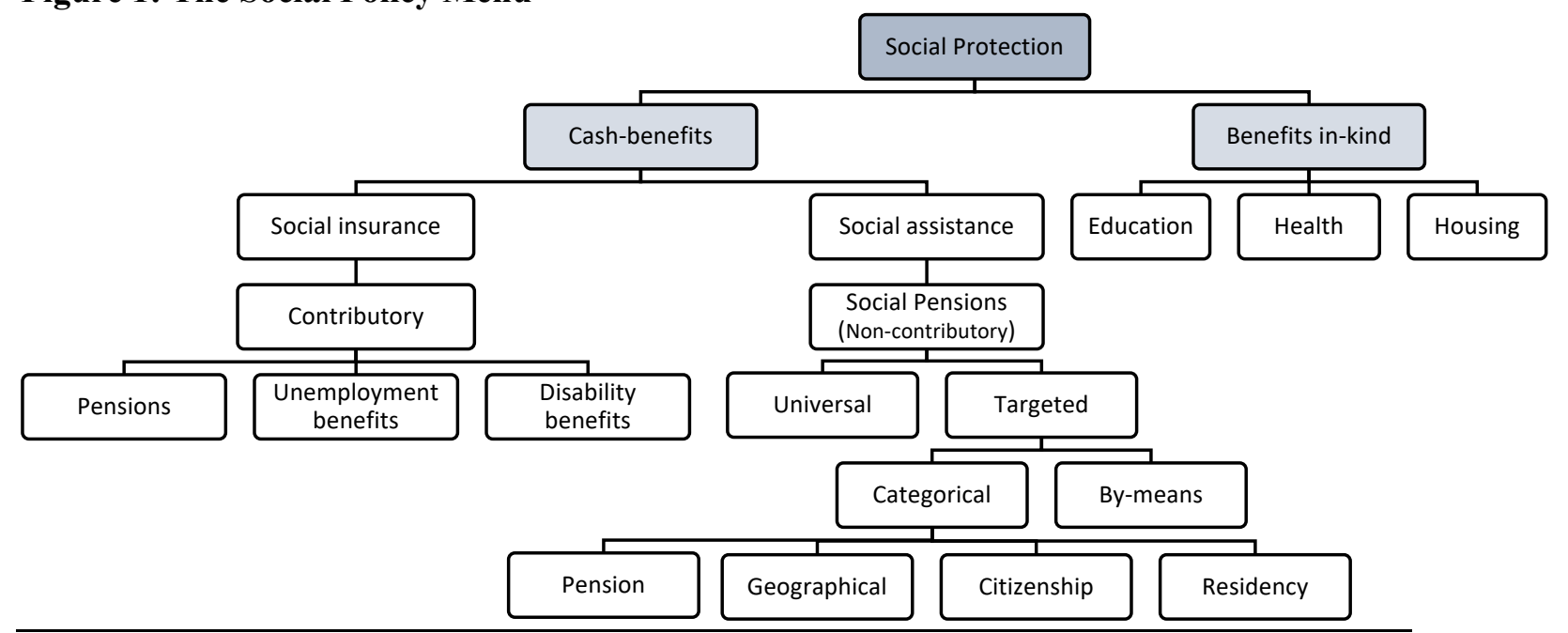

Elaborated by the author

Like any social protection program, social pensions can be universal - if available for everyone - or targeted - if available only for those who meet the eligibility requirements. By definition, social pensions involve targeting by including an age-eligibility requirement. However, the literature has considered that social pensions available to every resident-citizen above the age-eligibility requirement could be viewed as programs following a universal targeting criterion.

Social policy is universal if the entire population in a nation-state have access to it regardless of their class, citizenship, gender and status. Extensive coverage of the population needs to be combined with generous benefits - in terms of level and quality - and even distribution (i.e. equity in coverage and benefits) (Martinez-Franzoni \& Sanchez-Ancochea, 2016). Additional authors also incorporate a set of multiple criteria that must be fulfilled by a social policy to be considered universal (i.e. coverage, lack of segmentation, sustainable and equitable financing, and non-discretionary) (Cecchini, Filgueira, Martínez, \& Rossel, 2015; Pribble, 2013). This paper focuses on the coverage criteria when defining universalism.

With some exceptions (e.g., Uruguay, Argentina, Cuba, Costa Rica), most social pensions were established in the neoliberal era. Several authors have worked with the concept of neoliberal social policy. For example, Fischer (2020) refers to it as: "the range of publicly or collectively provided, funded and/or regulated services and interventions that principally target social provisioning". Sottoli (2000) distinguishes traditional social policy (pre-1980s neoliberal reforms) from new social policy (post-1980s reforms). According to Sottolli, the "new" social policy in the neoliberal era is characterised by a series of key concepts: compensation, selectivity/targeting, privatisation and decentralisation. Compensation is understood as introducing measures to cushion the social and political costs of the structural adjustment programs. Selectivity and targeting refer to selecting a group of "deserving individuals" to be the beneficiaries of the social policy programs/services (in contrast to a universal approach to benefits all). Privatisation and decentralisation refer to the total or partial transfer of the state's social tasks to private actors (for- and non-for-profit). Sottolli's characterisation of new social policy coincides with that of Vilas (1996). According to Vilas, neoliberal social policy was intended to be transitory until the structural adjustments reestablished the macroeconomic equilibrium and set economic growth back in motion. Vilas portrays neoliberal social policy as a charity, where cash transfers directed to the extremely poor aim to prevent them from sinking further into poverty. Non-contributory pensions, most of them targeted social assistance programs, acts in a compensatory manner to those unable to contribute enough to become beneficiaries of the Bismarckian pension programs.

Social assistance programs are not mutually exclusive with social insurance programs. Desai (2017) recently showed with a global dataset that "while coverage rates for social assistance are far more progressive than for social insurance, the benefits they provide are relatively paltry. Social insurance, on the other hand, provides greater benefits but remains regressive". Following this logic, social assistance should be seen as cash transfers to secure a basic income floor, but they do not substitute the contributory pensions. Countries can deliver universal policy outputs through a diverse set of instruments (e.g., social insurance and social assistance) and with welfare providers across different levels of government (Niedzwiecki, 2018; Pribble, 2013). 
Following the example of Uruguay's Monotax, countries in Latin America could develop programs that incentivise workers in the informal sector to move towards the formal sector and receive the benefits of the contributory welfare system (Durán-Valverde, 2014). In the meantime, universal social pensions would guarantee basic income security to the growing older-age population.

The national government is the primary funding source for social pensions in Latin America and the Caribbean (Social Security Administration, 2016). In 22 of the 30 social pension programs, the government is the sole funder; meanwhile, in Colombia and Costa Rica, the government plays a complementary funding role with the payroll contributions. The government plays a subsidiary role in the case of Bahamas, where the primary source of funding comes from covered earnings and covered payroll of residents (two per cent each). The case of Bolivia is unique as taxes on hydrocarbons and dividends from state-owned enterprises are the primary source of revenue to finance the 'Renta Dignidad' social pension (Müller, 2009).

However, as noted above, a part of social policy literature insists that universal social policy is unaffordable and calls for efficiently targeted programs.

Borgonovi and Compagni (2013) argue that critics sustain the unaffordability argument of universal health care because the growth rate of health care expenditure is higher than GDP growth. According to Midgley (2012), the economic crises, oil shocks in the 1970s and the end of the post-WWII economic growth era were used to support the unaffordability assumption of social protection. However, "the issue of funding social protection in the developing world is not a major cause for concern because these programs consume a relatively small proportion of the budget" (Midgley, 2012, p. 19).

On the contrary, there is also evidence of the affordability of universal social policy. Pal, Behrendt, Leger, Cichon, and Hagemejer (2005) used a simulation model to project costs of universal social policy in subSaharan countries and confirmed that at the end of the projection period in 2034, universal social pensions and universal access to primary education are affordable contrary to what may be assumed. Behrendt and Hagemejer (2009) and Cichon and Hagemejer (2007) also confirmed the affordability of a social protection floor in many low- and middle-income countries. Cichon (2018) go as far as to ensure that out of 150 countries studied by the Global Coalition for Social Protection Floors, only twelve countries would require intranational assistance to fund a basic social protection floor (Bierbaum, Oppel, Tromp, \& Cichon, 2016).

A fiscalisation and an efficiency discourse have driven the unaffordability myth. The dominant narrative in the fiscalisation discourse, according to Prince (2001, p. 9), is that "the public deficit is a grave problem that is the result of excessive spending". Universal social protection programmes are not only portrayed as unaffordable but as the causes of the fiscal deficits. This framing of the neoliberal discourse presents the welfare state programmes as inefficient, ineffective, outdated and unaffordable. At the same time, it legitimises market mechanisms and practices in social policy, shifting the aim of income redistribution to targeting social assistance to the deserving poor (i.e. the marketisation of social policy) (Prince, 2001; Stone, 1989). Stephen Devereux (2001, p. 516) confirms that allegations of fiscal unaffordability and unsustainability are generally used against the implementation of comprehensive and universal social protection programs in the global south, "though, in reality, all public spending allocations are policy choices".

The efficiency discourse rationale is simple, "it is more efficient to target specific groups than attempt universal coverage" (Midgley, 2012, p. 19). However, the broad exclusion and inclusion errors in targeting social protection reject the alleged efficiency. Development Pathways conducted a global review of the effectiveness of targeted social protection programmes in reaching the poorest. Out of 25 programmes with coverage under 25 per cent of their intended recipients, " 12 had exclusion errors above 70 per cent, and 5 had errors above 90 per cent" (Kidd \& Athias, 2019).

Research by Brown, Ravallion, and van de Walle (2018) shows the highly unsatisfactory results of the complex targeting mechanism favoured by the International Monetary Fund, the proxy-means testing. These researchers confirmed that, on average, 80 per cent of poor Sub-Saharan African households are declared non-poor and consequently excluded from targeted social assistance. In comparison, 40 per cent of non-poor households are counted as poor, thus included in the targeted social assistance scheme.

Even though targeting errors highlighted by the literature are evident, we must not forget that in order to provide coverage to either targeted or universal social policy, state institutions need to know who the beneficiaries are and where they are located. Here is where the identification of citizens is critical to provide any kind of social assistance, insurance or service. Hunter (2019) shows how means-tested CCTs (and noncontributory pensions) have played a key role in formalising many citizens on the Global South. However, we must also pay attention to the "dark side" of national registries and identification. Recent research by Hayes de Kalaf (2021) shows how the identification of citizens in national registries was used to exclude a 
part of the population from their social citizen rights in the Dominican Republic -the Haitian descent Dominicans. Therefore, legal empowerment matters, but it can play an inclusionary or exclusionary role with social citizen rights.

Countries have a multiplicity of options to create fiscal space and fund universal social pensions. The following sections contain a set of counterfactual exercises to test our central hypothesis and confirm or deny if a universal social policy is truly unaffordable.

\section{Reprioritising expenditure}

Reprioritising expenditure is a move from unproductive to productive spending (i.e., a move towards government spending with a direct impact on the societal wellbeing or productive capacity of the economy). Military expenditure, energy subsidies and potential illegal/odious external debt servicing are among the unproductive spending that could be redirected towards social protection.

\subsection{Military outlays}

The Stockholm International Peace Research Institute (SIPRI) defines military expenditures as the total current and capital expenditure on the following four areas: armed forces, defence ministries and other government agencies engaged in defence projects, paramilitary forces, and military space activities.

The global military expenditure increased by 2.6 per cent in real terms between 2019 and 2020 (the first year of the COVID-19 pandemic). Contrary to the world trend the military spending decreased in South America (-2.1 per cent) and Central America and the Caribbean (-0.2 per cent) (Lopes da Silva et al., 2021).

The military expenditure appears to be non-significant or negative in the long run for economic growth (Barro \& Sala-i-Martin, 2003). Using a sample of 82 countries for 1988-2008, Töngür and Elveren (2016) confirmed the negative impact of military expenditures on economic growth. Military spending also appears to affect income inequality. According to Taşıran and Elveren (2017), higher military spending increases income inequality in places with high-income inequality. Being Latin America the most unequal region globally (Roser and OrtizOspina, 2013; Cruz-Martínez, 2017), reducing military expenditures could help reduce income inequality by redistributing unproductive military spending to social protection. Paul Dunne, Perlo-Freeman, and Soydan (2004, p. 186) examined the impact of military expenditure and arms imports on the level of indebtedness in South America and found out that "military burden may be important in determining debt in countries, but it is only of significance when other macroeconomic and international factors do not swamp it". Therefore, a reduction in military expenditure is not expected to have a significant negative impact on the region's economic growth and could help reduce the unsustainable debt burden and income inequality.

One way to create fiscal space via military expenditures is to reduce it to the minimum possible to maintain national security. The SIPRI database provides data on military spending. However, the data is not disaggregated, thus not allowing assessing the unproductive military expenditures individually. Nonetheless, the military expenditure for Costa Rica could be used as an experimental threshold of the essential military expenditure to protect national borders and provide security. Costa Rica constitutionally abolished their armed forces in 1948. According to SIPRI (2017), the "expenditure for paramilitary forces, border guard, and maritime and air surveillance is less than 0.05 per cent of GDP". Contrariwise, the national annual budget shows that the public security budget is 0.8 per cent of GDP (Ministerio de Hacienda de Costa Rica, 2015). The higher national budget figure of 0.8 per cent is used as the threshold in this exercise.

Figure 2 shows the fiscal space that could be created if countries reduced their military expenditures to the Costa Rican level. On average, the region would create a space of $0.5 \%$ of GDP. Colombia is at the top of the list with a potential fiscal space of $2.6 \%$, followed by Ecuador (1.4\%), Uruguay (1.2\%) and Chile $(1.1 \%)$. Moreover, Guatemala, Nicaragua, Mexico and Dominican Republic would not be freeing up their budget by equalising the military outlays to the experimental threshold because their military expenditures are lower than Costa Rica's expenditure in public security.

The main limitation of this calculation is that the military expenditure in the SIPRI (2017) database includes a military pension. Therefore, a reduction to the Costa Rica levels will need to come along with a reform in the military pension system (e.g., transfer to the national or civil servant's pension fund). It is also relevant to recognise that all these countries have additional expenditure on police and security forces, 
which is not considered in their military expenditure. However, it is included in the Costa Rica security budget, which translates to more potential fiscal space creation by reducing military expenditure.

Figure 2: How much fiscal space could be created by reducing military expenditures to the Costa Rican

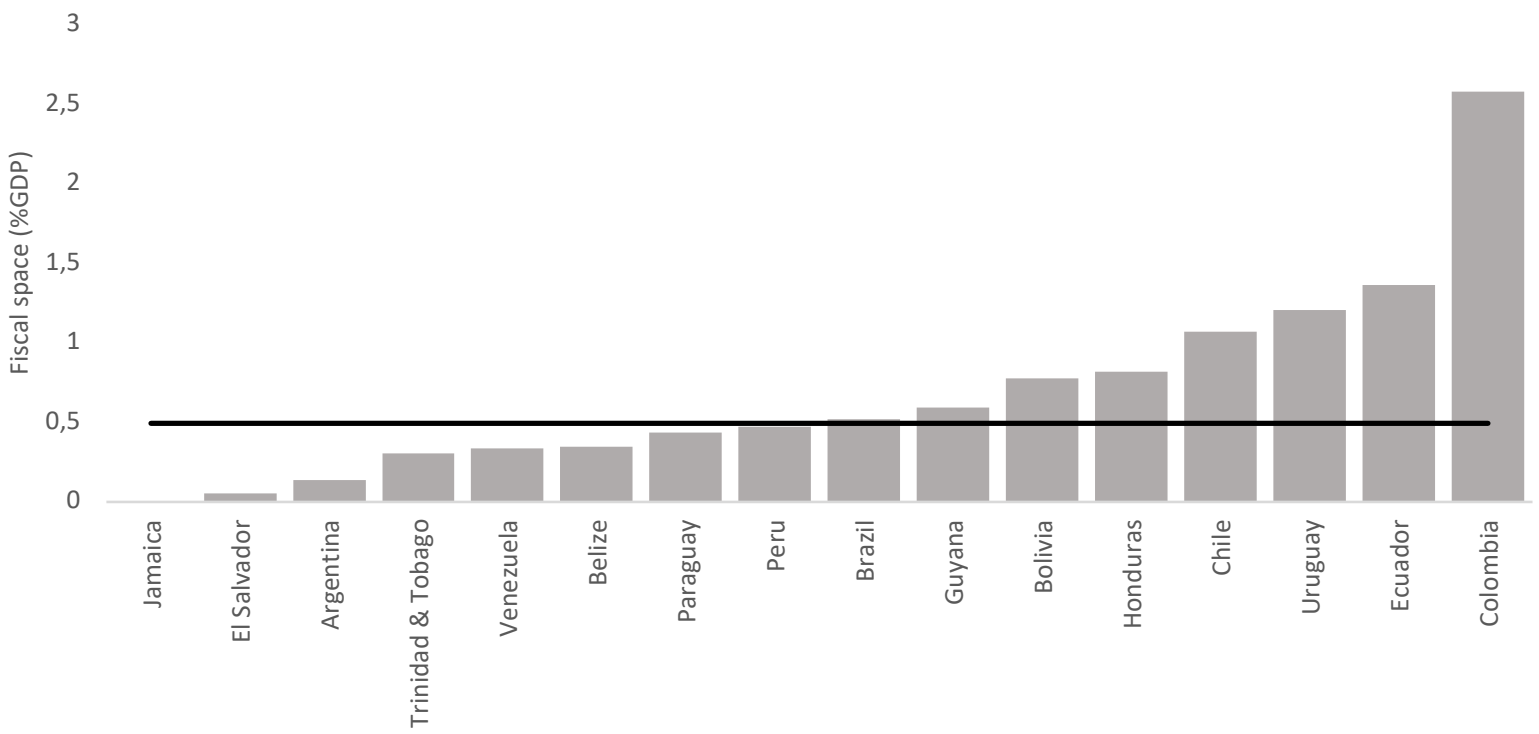

Notes: Data for 2016 except for Venezuela (2014). The total 2015 budgetary expenditures for the Ministry of Public Security in Costa Rica has used a threshold (237.667 billion of colones; 0.8\% GDP). 2015 GDP data comes from World Development Indicators. Guatemala, Nicaragua, Mexico and the Dominican Republic are excluded from the graph, as there is no potential of fiscal space creation with the Costa Rican public security expenditure as a threshold.

Author's calculations; Source: (Ministerio de Hacienda de Costa Rica, 2015; SIPRI, 2017; World Bank, 2017)

\subsection{Energy subsidies}

Fossil fuel subsidies are government actions (e.g., tax exemptions, direct funding, favourable energy rates) that keep the price of fossil fuels below market levels for consumers or above market levels for producers. Clements, Coady, and Piotrowski (2010) propose that reducing oil subsidies could effectively create muchneeded fiscal space while bringing environmental benefits to the picture. The rising cost of oil prices increased the oil subsidies in countries where governments were trying not to pass the increased cost to consumers entirely. If taxes are too low, the result is a consumer "tax subsidy". The global "tax-inclusive" consumer subsidy is between US\$ 544 billion (Mason, 2016, p. 249) to US\$ 740 billion (Clements et al., 2010 , p. 42). However, what about the region of interest in this paper?

Latin America and the Caribbean spent an estimated 1.8\% of their GDP in 2011-2013 on energy subsidies, approximately evenly split between electricity and fuel (Di Bella et al., 2015). The previously cited group of researchers concluded that countries with weaker institutions tend to incur higher subsidies, energy-rich countries direct most fuel subsidies, and low-income countries in the region subsidise mainly electricity.

IMF argues that petroleum product subsidies do not benefit the poorest as it is commonly believed. Gasoline subsidies are the most regressive. In Latin America, 38 per cent of the benefits of petroleum product subsidies benefit the wealthiest 20 per cent of households, while the bottom 20 per cent obtain 6 per cent of the benefits (Clements et al., 2010). Besides not being an effective instrument for income redistribution (e.g., top 20 per cent captures six times more subsidies than the bottom 20 per cent), Arze del Granado, Coady, and Gillingham (2012) argues that fuel subsidies distort production and consumption decisions. Therefore, reducing energy subsidies - mainly oil subsidies - creates fiscal space for social protection without implementing a regressive measure against low-income households. Also, it brings positive externalities to health and the environment. The IMF estimates that eliminating these subsidies could reduce deaths related to emissions by 50 per cent and reduce fossil fuels related carbon emissions by more than 20 per cent (Coady, Parry, Sears, \& Shang, 2015).

A decrease in oil subsidies increases the price of fuel, which might hurt the welfare of households. Nonetheless, Breisinger, Engelke, and Ecker (2012) have shown that the overall effects of reducing oil 
subsidies are positive, and monetary poverty decreases if there is compensation with direct cash transfers to households.

Figure 3 shows the potential fiscal space that could be created by reducing oil, electricity and gas subsidies by 25 and 50 per cent. Coady et al. (2015) provide pre-tax and post-tax energy subsidies global data in petroleum, coal, natural gas and electricity. For the fiscal space analysis, the 2015 value for pre-tax energy subsidies is used. There is data available for thirty-one countries in the region.

Figure 3: How much fiscal space could be created by reducing energy subsidies by 25 per cent and
50

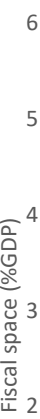

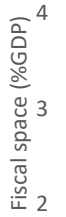

1

0

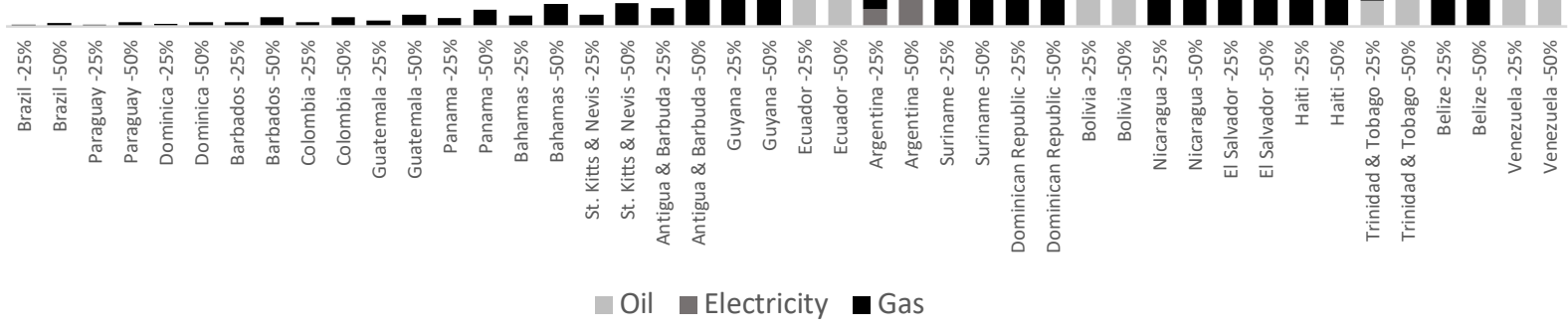

Notes: Data for 2015. Chile, Costa Rica, Jamaica, Mexico, Peru, St. Lucia, St. Vincent and the Grenadines, and Uruguay do not have energy subsidies according to the IMF data; therefore, they are excluded from the graph. Also, the coal category is also excluded as all countries exhibit zero subsidies in this category. Each country is represented two times. ' $-25 \%$ ' shows the fiscal space created by reducing subsidies by 25 per cent, while ' $-50 \%$ ' shows the same analysis but with a 50 per cent reduction. Petroleum includes subsidies for gasoline, diesel and kerosene.

Author's calculations; Source: (Coady et al., 2015)

On average, the region could create $0.6 \%$ of GDP in fiscal space by halving the energy subsidies and $0.3 \%$ if energy subsidies are reduced by a quarter. Electricity is the sub-category contributing the most to the potential fiscal space creation, followed by petroleum and natural gas. For example, electricity subsidies represent $62 \%$ of the $0.6 \%$ GDP of possible fiscal space, while petroleum subsidies represent $29 \%$ and natural gas subsidies $9 \%$.

Venezuela has the most significant potential for fiscal space creation via reducing energy subsidies, especially those related to petroleum. Venezuela would be able to create a 5.2\% GDP by reducing energy subsidies by half. Furthermore, Figure 3 shows that Belize, Trinidad and Tobago, Haiti, El Salvador, Nicaragua, Bolivia and the Dominican Republic would create around 1\% GDP by reducing energy subsidies by half. The results show that eight countries have zero energy subsidies and all thirty-one countries have zero subsidies for coal.

There is a strong relationship between top energy subsidisers and top energy producers. The only four petroleum subsidisers are in the top 10 list of petroleum producers per capita. 


\subsection{Auditing and restructuring debt}

The region has experienced several debt crises in the last century. Between 1926 and 1932, the debt to export ratios was threefold (Armendáriz \& Larraín B., 2017, p. 89). The 1930s debt crisis was temporarily resolved by restructuring and renegotiating with creditors.

The 1980s debt crises hit the region hard as well, only Colombia escaping defaults. After the debt restructuring process - the so-called Brady Plan - led by the International Monetary Fund, the conditional structural adjustments and market-oriented reforms spread through the region (i.e., trade liberalisation, privatisation, price stabilisation). Williamson (1990) pointed out the ten neoliberal policy reforms prescribed by political Washington and the technocratic Washington (i.e., the Washington Consensus).

In the XXI century, Argentina (2001, 2020), Ecuador (2008), and Puerto Rico (2016) entered into the process of debt defaults and restructuring. The 2001 default in Argentina followed the 1930s defaults strategy of 'take-it-or-leave-it offer' in which 76 per cent of bondholders agreed to a 75 per cent haircut (Macías Vázquez, 2008) after negotiations with creditors.

In 2017, Puerto Rico entered into a restructuring court-supervised process of its debt. The former Puerto Rico Commission for the Comprehensive Audit of the Public Credit (2016) argued that funds raised in the last two debt issuances ( $\$ 3.5$ bn' junk bond' emission and tax revenue anticipation notes) exhibit several unconstitutional features (e.g., using funds to reduce deficit-spending, breaching constitutional limits). However, the auditing process was interrupted by the Rossello administration after eliminating the debt audit commission (Law 22, 2017). Here is where the case of Ecuador can shed some light on the benefits of an auditing process.

By an executive decree, the Ecuadorian government created in 2007 the Commission for the Comprehensive Audit of the Public Credit. The Commission's primary role was to establish the legitimacy, legality and relevance of the loans, negotiations and renegotiations between 1976-2006 (CAIC, 2008). In 2008 the government declared illegitimate debt issued as sovereign bonds, forcing bondholders to accept a 65 per cent face value reduction via a bond buyback, saving interest payments of around US\$ 7 billion on bonds maturing in 2012 and 2030 (Chatzistefanou \& Kitidi, 2011; Toussaint, 2012).

Creditors and debtors should share responsibility for preventing and amending unsustainable debt situations (UNCTAD, 2012). The establishment of national debt audit commissions could be the first step to examine and eliminate illegal and illegitimate debt and to establish a guideline for future sustainable debt issuance.

It is difficult to establish an experimental threshold to calculate the potential fiscal space creation after an auditing process. Mainly because each country has a different history of debt issuances and autocratic governments; nonetheless, this section examines the potential fiscal space that could be created if countries reduced their total debt service by 25,50 and 75 per cent after an auditing process. "Total debt service is the sum of principal repayments and interest paid in currency, goods, or services on long-term debt, interest paid on short-term debt, and repayments (repurchases and charges) to the IMF" (World Bank, 2020). Data comes from the World Bank International Debt Statistics database and is available for 24 countries.

As shown in Figure 4, Latin American and Caribbean countries would be able to create up to 1.4 per cent GDP - on average - with a debt auditing process leading to a 25 per cent reduction in the total debt service on external debt. Accordingly, a 50 per cent reduction would create a fiscal space of 2.8 per cent GDP, and a 75 per cent reduction would make up to 4.2 per cent GDP.

Jamaica tops the list with a potential 7.1 per cent GDP by reducing total debt service by a quarter. Paraguay, Dominican Republic, Nicaragua, Venezuela and Honduras could make room in their budget above 1.5 per cent GDP after auditing and restructuring, leading to a 25 per cent reduction in the total debt service.

An auditing process could determine the interest rates of complex financial products used in foreign debt issuance as odious and abusive. For example, a report by ReFund America Project (2016) calculated that Puerto Rico owes US\$37.8bn in capital appreciation bonds. The underlying principal is US\$4.3bn, and the remaining US $\$ 33.5 \mathrm{bn}$ represents interest payments. Therefore, interest is up to $781 \%$ higher than the actual money borrowed by the government. This astronomic figure of interest payments could be used to dispute the legitimacy of the debt issuance across Latin America and the Caribbean. 

cent?

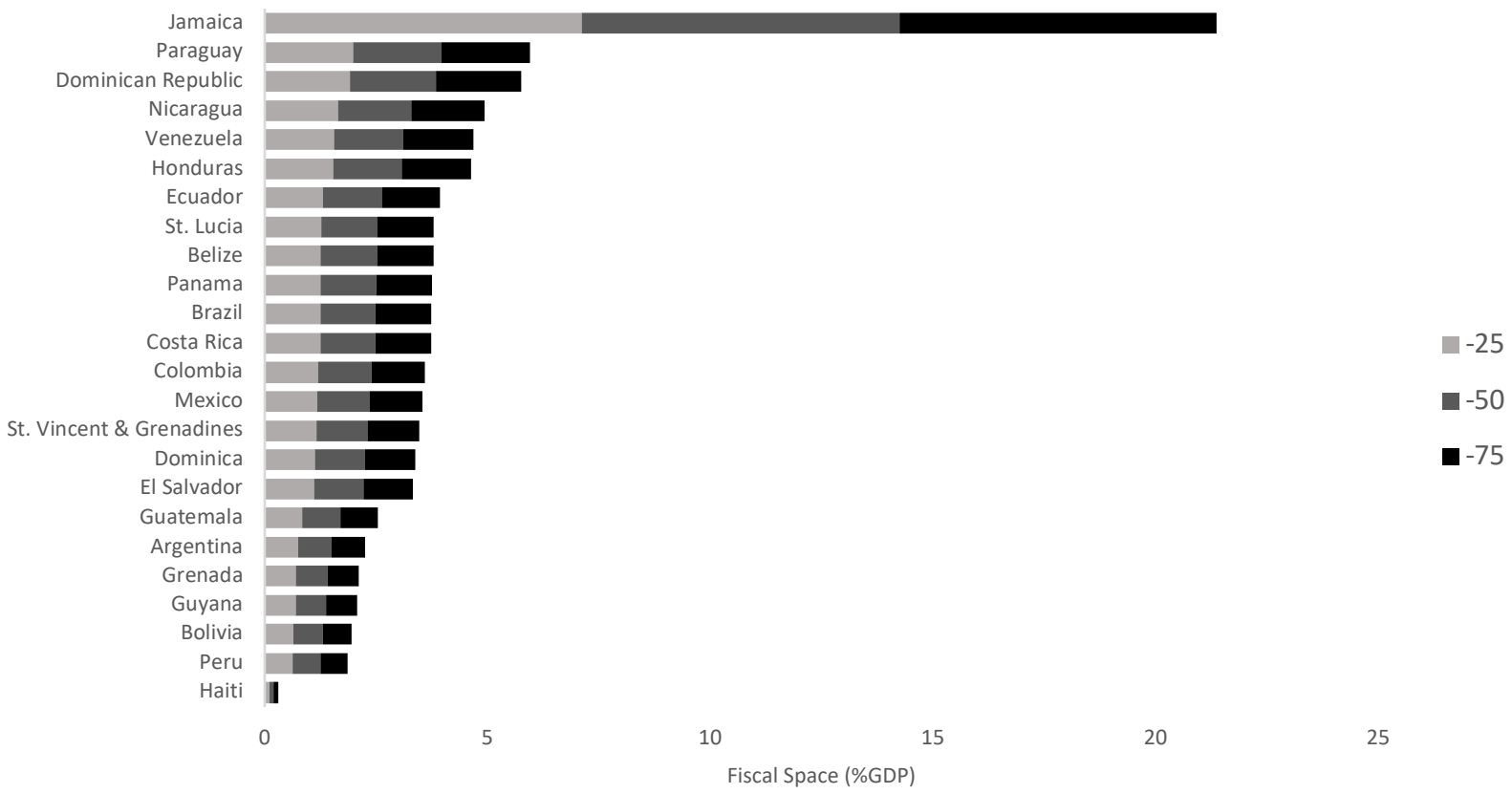

Notes: Data for 2015, except Venezuela (2013). ' $-25 \%$ ' shows the fiscal space created by reducing total debt service on external debt by 25 per cent, while ' $-50 \%$ ' and ' -75 ' shows the same analysis but with a 50 and 75 per cent reduction.

Author's calculations; Source: World Bank (2017)

\section{The revenue side}

"Fair and effective tax systems can help collect much more in additional resources than equally complex individual means-testing mechanisms could ever save" (Cichon, 2018, p. 15). Therefore, the revenue side must be included in the fiscal space creation analysis. The following section examines the revenuegenerating potential of progressive tax reforms to funding social pensions. This section considers two experimental tests: increasing income tax rates to individuals in the top 1 and 5 per cent of the income share and temporarily increasing trade taxes until reforms addressing the relatively low domestic tax revenues are addressed.

\subsection{Income tax}

Direct taxes on income are levies by public authorities at regular intervals, on the individual or household income such as employee compensation, property income and pensions (OECD, 2014). This type of tax is generally considered a progressive tax, which means that higher-income earners contribute more than lower-income earners. Latin American tax systems have become less regressive during the last decade; however, compared to Europe, the region redistributes much less and "collect less in revenue (as a proportion of GDP) from income taxes than do those from any other region of the world" (Mahon, 2012, p. 1).

The literature argues that the sizeable informal sector and a regressive and non-institutionalised taxation system are among the financial limitations to implement sustainable social welfare systems in Latin America (Cruz-Martínez, 2015, 2019). However, there are multiple options to increase government revenue and create fiscal space for social protection. For example, four countries in the region have zero income tax rates (Anguilla, Bahamas, Bermuda and Cayman Islands). Twenty-six countries have a top income tax rate lower than the OECD average (41.7 per cent). Therefore, it is difficult to justify there is little room to manoeuvre to increase revenues and create fiscal space by increasing the income tax rates on the wealthiest groups of the population, especially if we compare current top income tax rates with the ones before the neoliberal era. Since 1979 the region has considerably reduced their income tax rates (e.g., Bolivia from 
$48 \%$ to $13 \%$, Brazil from $55 \%$ to $27.5 \%$, Chile from $60 \%$ to $35 \%$, and Colombia from $56 \%$ to $33 \%$ ) (Reynolds, 2019).

Using data from the World Wealth and Income Database (now the World Inequality Database) (Alvaredo, Atkinson, Piketty, Saez, \& Zucman, 2016) and the formula proposed by Piketty, Saez, and Stantcheva (2011b), this section calculates the potential fiscal space created by increasing average income tax rates on the wealthiest individuals in the three Latin American countries (top 1 per cent and top 5 per cent income share) with available data. The formula is:

$$
\text { Fs=is_x t }
$$

Where Fs is the fiscal space created - in percentage points of GDP, $\mathrm{i}$ is the total market income reported for tax purposes - in percentage points of GDP, $\mathrm{s}$ is the income share of the top x per cent excluding capital gains - in this case, the top 1 and 5 per cent, and t is the tax rate experimental increase - in percentage points.

Figure 5 shows the potential fiscal space of both tests - increasing tax rates of the top 1 and 5 per cent - for Argentina, Colombia and Uruguay. On average, an increase in 5 percentage points on the average tax rate of the wealthiest 1 per cent creates a fiscal space equivalent to 0.5 per cent of GDP, 0.9 per cent of GDP for an increase in 10 percentage points, and a fiscal space equivalent to 1.9 per cent of GDP for an increase in 20 percentage points. This represents circa 53 per cent more fiscal space creation than for the average of 22 middle- and high-income countries with available data in the World Wealth and Income Database.

Figure 5: How much fiscal space could be created by increasing the average tax rate to the top 1 per
cent
and

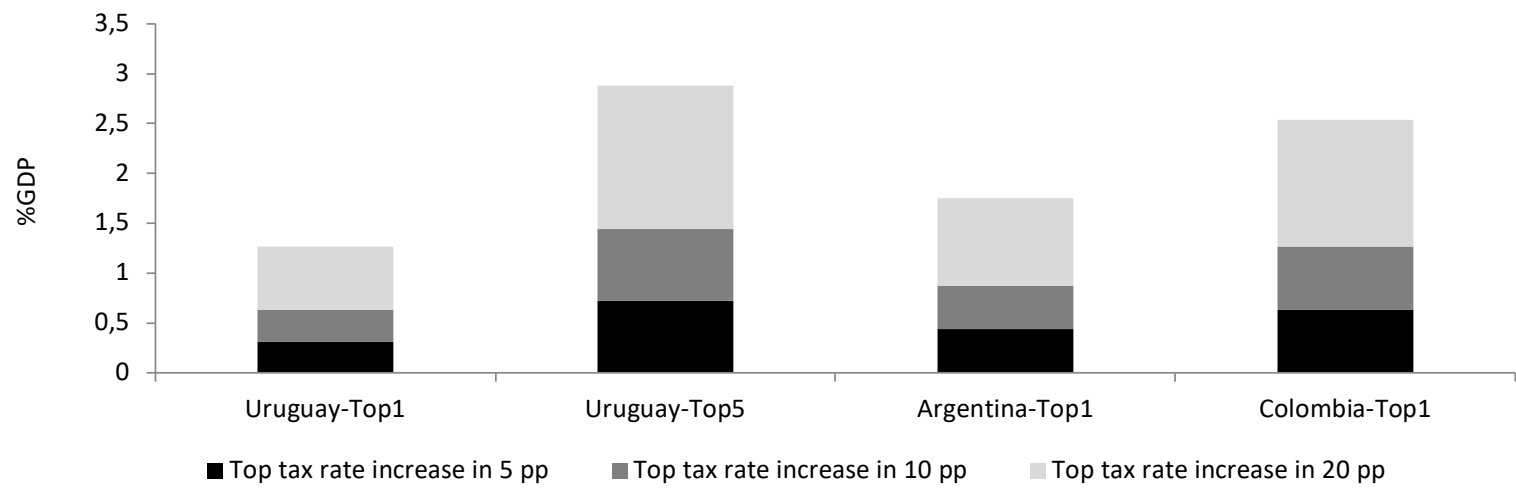

Notes: The graph shows the potential fiscal space created by increasing the average tax rate of the top 1 per cent and 5 per cent income share by 5 (first level), 10 (second level) and 20 (third level) percentage points. Data on the total market income (pre-tax) and the income share of the top 1 per cent and 5 per cent comes from the World Top Incomes Database. All countries with available data are included. There is no available data on the top 5 per cent income share for the cases of Argentina and Colombia. GDP data comes from the World Bank.

Author's calculations; Sources: (Alvaredo et al., 2016; CEDLAS \& World Bank, 2016)

Uruguay is the only country with data for the top 5 per cent income share. The same three tax rate increases on the Uruguayans richest 5 per cent creates a potential fiscal space equivalent to $0.7,1.4$, and 2.9 per cent of GDP. Compared to the average fiscal space created for the 22 countries in the World Wealth and Income Database, Uruguay creates 14 per cent more fiscal space.

Supply-side economists would discourage this proposal, arguing that increasing income tax rates undermine economic activity by crowding out investment, business creation and employment creation. Besides, increasing tax avoidance and reducing productivity and work effort by the working population (Engen \& Skinner, 1996; Feldstein, 1995). Nonetheless, Piketty, Saez, and Stantcheva (2011a) argue that the optimal top income tax rate in a sample of 18 OECD countries is between 57 and 83 per cent - even after considering multiple potential negative externalities. Therefore, if this range of optimal top income tax rates were extrapolated to the three countries in the sample, none would surpass the 57 per cent lower bound even after increasing their top income tax rates by 20 percentage points.

In 2012, the U.S. State of Kansas implemented a tax reform that lowered the top income tax rate by $24 \%$ and eliminated some corporate income tax rates for partnerships and corporations. Gale (2017) highlights 
three lessons learned from the Kansas tax reform: tax cuts do not boost economic growth, special corporate tax rates do not create new business activity, and third individuals prefer higher revenues and more government expenditure over lower taxes and draconian austerity reforms.

Gale is not the only researcher dispelling supply-side economists' myths about the alleged positive effect of low tax rates on economic activity. There is no significant positive relationship in the literature between lowering top income tax rates and an acceleration in the economic growth (Garfinkle, 2005; Hungerford, 2012), nor in the generation of employment growth (Gale, Krupkin, \& Rueben, 2015).

\subsection{Trade tax}

Trade taxes are generally referred to as tariffs. Tariffs are customs duties on merchandise exports or imports. Trade tax compliance is more accessible to achieve - even in countries with weaknesses in tax administration - than other types of taxes as the frontier formalities needed to tax goods entering and leaving the country usually is straightforward. This relative simplicity has made trade tax revenue one of the primary sources of tax revenues in low- and middle-income countries (Hisali, 2012).

During the last decades of neoliberalism, the trade liberalisation process promoted under the auspices of the World Trade Organization (WTO) has reduced trade tariffs to low levels (Smith, 2015). Henceforth, government revenues have been reduced, and social welfare programs cuts due to the alleged incapacity of governments to raise revenue (Fernández Arias, 2003). In the trade liberalisation era, middle- and lowincome countries have not replaced trade tax revenues with domestic tax revenues as high-income countries have been able to do (Baunsgaard \& Keen, 2010). Therefore, the timing, degree and unplanned trade liberalisation has hampered governments' ability to collect revenues in low- and middle-income countries. Latin American countries are also part of the group of hindered countries. Fricke and Süssmuth (2014, p. 114) argue that the region is transitioning "from an international trade taxes regime to raising revenues from other tax categories".

Could Latin American and Caribbean countries increase trade taxes until other sources of revenues are secured? Ortiz et al. (2015, p. 17) consider the examination of tariff rates as a transitory measure for lowand middle-income countries "until domestic tax collection mechanisms are strengthened to sustain or increase levels of [government] revenue'. There is space to increase trade taxes as none of the 15 countries with data available has surpassed the tariff rate ceiling agreed with the WTO.

Using tariffs data from the WTO (2016) and data for imports of goods and services from the CEDLAS and World Bank (2016), this section calculates the potential fiscal space created after increasing tariffs by - an experimental -5 and 10 per cent. The formula is:

$$
\mathrm{Fs}=\left(\mathrm{t} \_\mathrm{MFN}+\mathrm{t} \_\mathrm{x}\right) \operatorname{Imp}
$$

Where Fs is the fiscal space created - in percentage points of GDP, $t$ _MFN is the simple average applied MFN tariff on goods as reported to the WTO, $t$. $x$ is the experimental tariff rate increase in $\mathrm{x}$ per cent - in this case 5 and 10 per cent - and Imp is the total imports as a percentage of GDP.

Figure 6 shows the potential fiscal space created by increasing the most favoured tariffs rates in 5 and 10 per cent in 15 countries in the region. On average, the Latin American and Caribbean region could create revenues equivalent to 0.5 per cent of GDP by increasing the tariffs by five per cent and a fiscal space of 1 per cent of GDP by increasing tariffs by ten per cent. The Central American countries of Honduras, Panama, and El Salvador would benefit the most with a fiscal space creation above 1.5 per cent GDP after increasing their average MFN tariffs.

As expected, there is a strong correlation between the degree of trade openness ratio and the potential fiscal space creation. Closed economies (e.g., Cuba, Brazil, Argentina) have the least potential for fiscal space creation in this exercise, and open economies (e.g., Honduras and Panama) - with a trade openness ratio above 100 per cent (World Bank, 2020) - have the highest potential for fiscal space creation via trade taxes. Now, the five and ten per cent experimental tariffs increase should not be considered a policy recommendation for all countries in the region. Each case should be examined on a one to one basis to avoid undesired macroeconomic imbalances. 
Figure 6: How much fiscal space could be created by increasing the average tariff rate in 5 and 10 per cent?

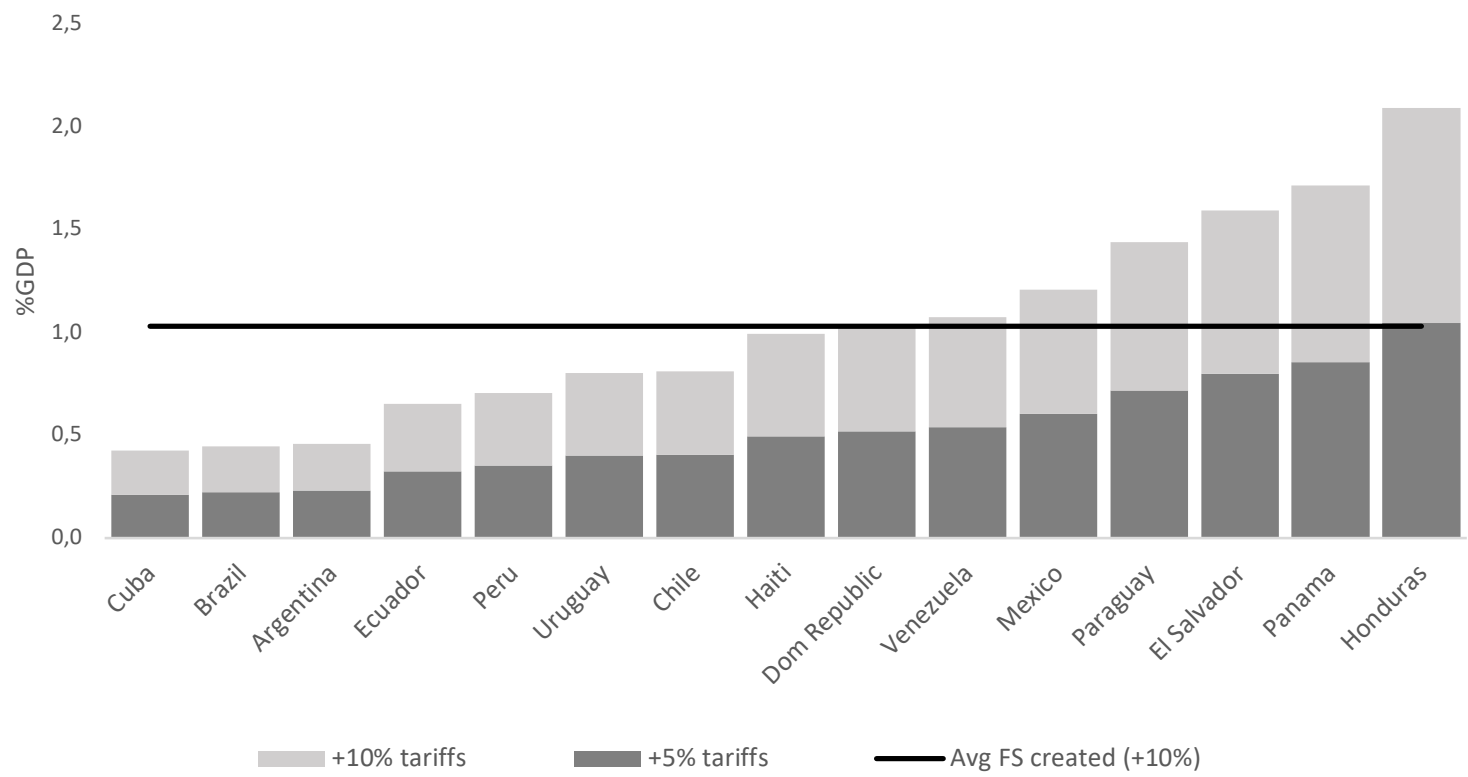

Note: The product of a 10 per cent increase in the tariffs and the value of all imports was used to estimate the fiscal space creation. See the formula in the text. The horizontal line shows the average fiscal space created in the sample with a 10 per cent increase in tariffs. The dark bar shows the fiscal space created by increasing tariffs in 5 per cent, and the light bar indicates the fiscal space after increasing tariffs by 10 per cent.

Author's calculations; Source: (CEDLAS \& World Bank, 2016; WTO, 2016)

\section{Discussion: Aggregating the potential fiscal space to fund universal social pensions}

Are universal social pensions in the region unaffordable? This section addresses the main research question derived from the counterfactual exercises. In addition, it provides us with an idea of the potential funding power of the five experimental fiscal space strategies created by increasing tax revenues and reprioritising expenditure from unproductive to productive areas. The section ends with a brief discussion on political affordability and the coexistence of universal social pensions with existing pension schemes.

First, what is the cost of a universal social pension for the thirty-one countries included in the previous sections? The cost of a universal social pension is calculated using a modified model of Willmore's (2007) formula. The model (see formula 3) incorporates five per cent of the total cost of transfers as an administrative cost, as proposed by Knox-Vydmanov (2011, p. 3). A second model (see formula 4) subtracts the actual cost of the current social pensions (in percentage points of GDP) to the potential cost of a universal social pension. Age-disaggregated data for 2020 comes from the United Nations Population Division (UNPD, 2019). Expenditure for current social pensions come from the ECLAC (2020) database on non-contributory pensions. The formulas given are:

$$
\begin{aligned}
& \mathrm{C}=\mathrm{rp}+\mathrm{Ac} \\
& \mathrm{Nc}=\mathrm{C}-\mathrm{Ex}
\end{aligned}
$$

In formula 3, $\mathrm{C}$ is the cost - in percentage points of GDP - of a basic universal non-contributory pension, $\mathrm{r}$ is the ratio of the flat pension to per capita GDP (pension level), $\mathrm{p}$ is the proportion of the population eligible for pensions (age eligibility), and Ac is the administrative cost of the transfer. (Cruz-Martínez, 2018. In formula 4, Nc is the net cost -in percentage points of GDP- of a basic universal non-contributory pension, $\mathrm{C}$ is the cost of the basic universal non-contributory pension calculated in formula 3, and Ex is the expenditure of the current targeted non-contributory pension. Therefore, formula 3 calculates the cost of a potential basic social pension and formula 4 the net cost after subtracting the current targeted social pension. 
On average, the cost of a universal social pension for the 31 countries sample with a benefit level of 20 per cent GDP per capita is 1.9 per cent GDP (age eligibility of 65), and 2.7 per cent GDP (age eligibility of 60). Now, if we subtract the existing cost of targeted social pensions - with an average cost of 0.3 per cent GDP - the net cost of a universal pension for everyone above 60 years of age is 1.6 per cent GDP, and for everyone above 60 years of age is 2.4 per cent GDP.

The bars in Figure 7 shows the aggregated fiscal space after adding the budget room created in five of the tests. The reprioritising expenditure categories are reducing military outlays to the cost of public security in Costa Rica, reducing energy subsidies by half, and a debt auditing process leading to a 25 per cent reduction in the total debt service on external debt. On the revenue side, the two tests are an absolute increase of 10 percentage points in the average tax rate to the top one per cent and a 10 per cent increase in the average tariff rate. The case of Guyana stands out for having a negative net cost for a universal social pension (age eligibility 65). The reason is simple; the existing targeted social pension costs more than the potential universal version.

Figure 7: Net cost of universal social pensions versus the funding power of the aggregated experimental fiscal space created by increasing tax revenues and reprioritising expenditure

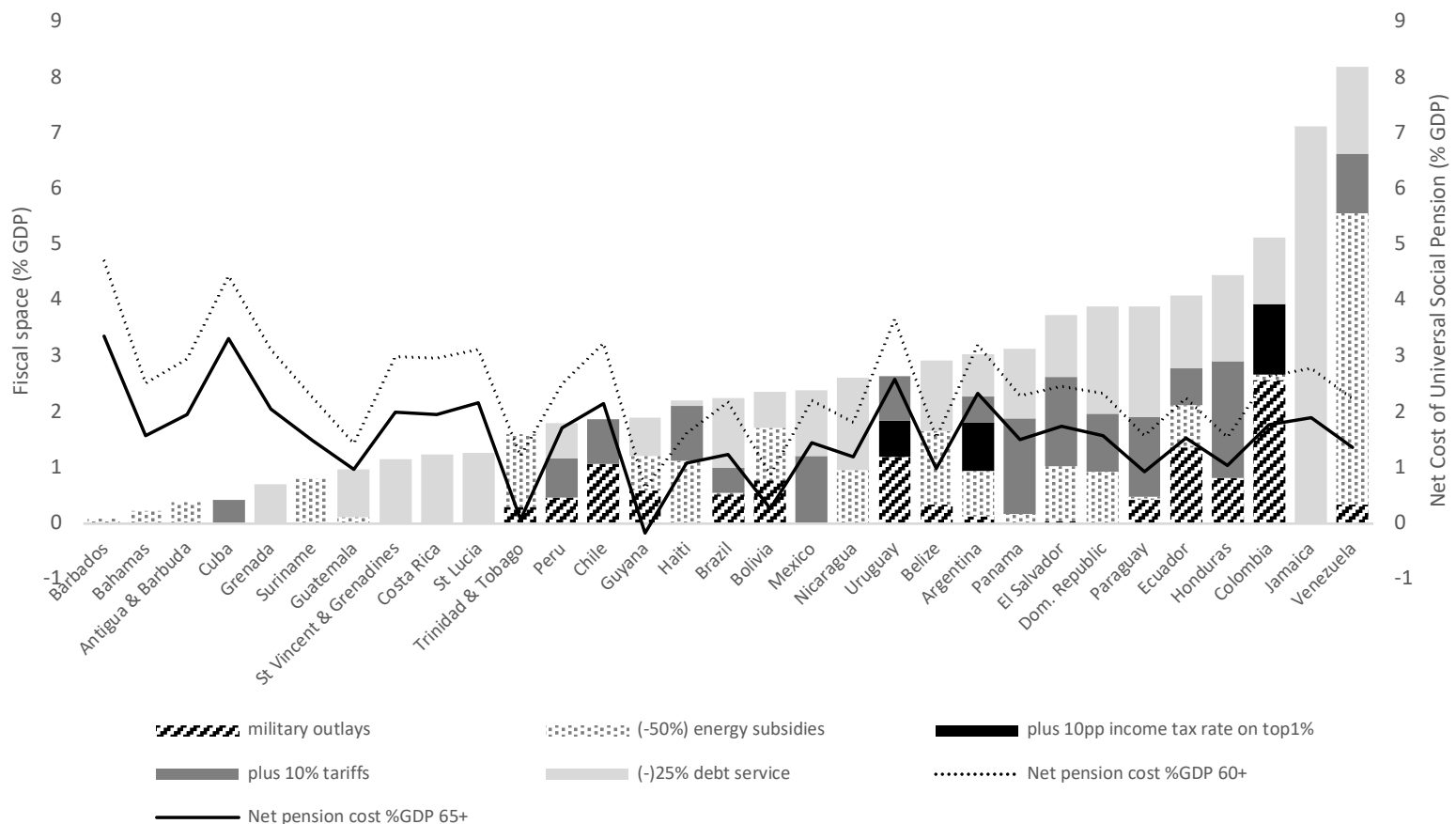

\footnotetext{
Notes: The fiscal space is in bars (left-Y axis) and the net cost of universal social pensions is in lines (right-Y axis). The benefit level for universal pensions is set at 20 per cent of GDP per capita. Net pension cost refer to formula 4 . Six countries have data available for one of the exercises, four have data in two exercises, ten have data in three exercises, ten have data in four exercises, and one has data on all five counterfactual exercises. Dominica and St Kitts and Nevis are excluded because there is no age-disaggregated data at UNPD.

Author calculations; Sources: (Alvaredo et al., 2016; CEDLAS \& World Bank, 2016; Coady et al., 2015; Ministerio de Hacienda de Costa Rica, 2015; SIPRI, 2017; UNPD, 2017; World Bank, 2017; WTO, 2016)

Sixty-five per cent of the cases have data on three or less of the fiscal space creation exercises. Nonetheless, this is not a limitation to show the excellent funding potential of only five of the multiple sources of fiscal space. On average, the region creates a fiscal space equivalent to 2.5 per cent of GDP with these five sources. Each of the five strategies used in the paper creates a recurrent budget room required for a sustainable social assistance program such as social pensions. Each country could examine additional fiscal space sources - not considered in this paper - which might create a one-off lump-sum revenue source. For example, countries could create up to 6.3 per cent GDP - on average - after an auditing process leading to a 25 per cent discount of the total face value of their government's foreign debt. This and other kinds of one-off revenue sources could be used to create a social protection fund.
} 
In Figure 7, the solid line shows the net cost of a universal social pension with an eligibility age of 65 . In contrast, the dotted line presents the net cost of a pension with an eligibility age of 60 . The experimental analysis shows that 20 countries could have sufficient funding power to finance a social pension for everyone above 65 years of age and 17 for everyone above 60 years of age.

Each country would need to examine the pension level and age of eligibility before a policy recommendation. However, after only considering five of the multiple fiscal space sources, this section shows that it is difficult to claim that basic universal social pensions are economically unaffordable.

Now, even though the unaffordability claim is debunked, we must critically reflect on other factors besides fiscal costs that are necessary to implement universal social assistance. Seekings (2017) highlighted the relevance of going beyond the fiscal costs to examine affordability. He talks about an "affordability gap" to show that even though four Anglophone East and Southern African countries have the fiscal space to expand social protection, national policy-making elites have resisted or rejected such reforms. Buchanan \& Musgrave (1999) considers interest groups inside and outside the government in the examination of public policies and budget allocation. Pal et al. (2005) also argue that basic social protection can be affordable, but it must become a priority at the national level. Another implementation challenged is the lack of reliable management and information systems (Guven Leite, 2016), which makes it difficult to verify the age of potential beneficiaries, might delay the cash transfer to the beneficiary due to IT system failures (Bukuluki \& Watson, 2012), or might prevent beneficiaries from showing an identity card to receive the transfer due to lack of identity papers (Müller, 2009).

A universal social pension scheme will continue to be the first pillar -social protection floor- of the pension system. It does not aim to substitute contributory pensions (second pillar) or the private individually funded pensions (third pillar) because the pension level of an affordable social pension will necessarily be basic (at least on the first stage). Konx-Vydmanov (2011) shows that many pensions have a benefit level between ten to twenty per cent of the GDP per capita. The main difference between existing targeted social pensions and potential universal social pensions is that every older-age resident in the country would receive a basic regular income regardless of their citizenship, income level, place of residence, legal status, or access to a contributory or private pension scheme; thus, transforming the basic social protection floor for the older age from targeted to universal, and from a social citizenship right to a human right.

\section{Conclusion}

The revenue-generating potential of taxes and reprioritising expenditures from unproductive to productive areas appears to be enough to finance -entirely or partly- basic universal social pensions in large parts of Latin America and the Caribbean. On average, the region could be able to create $0.6 \%$ of GDP in fiscal space by halving the energy subsidies, $0.5 \%$ of the GDP by reducing military expenditures to the Costa Rican level, and 1.4 per cent GDP after a debt auditing process leading to a 25 per cent reduction in the total service on external debt. The revenue side also offers a sizable potential for fiscal space creation. An increase in 10 percentage points on the average tax rate of the wealthiest 1 per cent creates a fiscal space equivalent to 0.9 per cent of GDP and an average of 1 per cent of GDP by increasing tariffs by ten per cent.

The main limitation of the analyses conducted here is that these are lab/experimental tests on the unaffordability assumption. Consequently, further econometric analysis is needed to prove the adequacy of such fiscal space creation policies. Microsimulations can inform countries on the particularities of implementing universal social pensions and how they might interact with the tax code (Jouse \& Rattenhuber, 2018). Latin American and Caribbean countries have different socio-economic realities and challenges that must be considered individually. However, this paper has shown that the unaffordability argument is a myth. Multiple possibilities could be regarded as moving away from limited and residual neoliberal social policy towards universal social assistance and (complimentary) contributory social insurance programs.

Second, It is also important to highlight that there are other social assistance programs (e.g., cash transfers for the younger population) or benefits-in-kind (e.g. healthcare) that should be considered by each of the countries when testing the fiscal space creation strategies and affordability of a potential universal coverage. Countries might fund the universal coverage in one but not all of the social assistance programs. This was pointed out previously by Hagen-Zanker \& McCord (2013) when considering that six social protection programs could be affordable at the individual level in five African countries but not jointly affordable.

Third, we cannot incorporate all revenue sources or test additional expenditure redirection exercises due to space limitations. As previously mentioned, data availability and the potential for fiscal space creation were used as the criteria to include each revenue source. Now, it is relevant to point out that having additional 
sources of tax revenues (domestic or not) or testing with additional expenditure redirection strategies will only support even more the findings of the paper because the potential fiscal space creation would be larger. Lacking a balanced panel with data for all countries in each of the tests limits the hypothesis testing power. Still, it does not compromise the paper's aim: testing if social pensions are unaffordable. If we could incorporate data for all countries and indicators into the analysis, the potential fiscal space will only increase - thus making our argument stronger.

Further analysis might consider evaluating additional progressive reforms to create fiscal space such as the one mentioned in the theoretical framework section. Moreover, they might examine countries individually to test the economic and political affordability of these fiscal space creation strategies.

Scholars and policymakers can disagree on the best approach to create fiscal space on a country-by-country basis. Still, the fact is that universal social policy is not economically unaffordable. 


\section{References}

Alvaredo, F., Atkinson, A. B., Piketty, T., Saez, E., \& Zucman, G. (2016). The World Wealth and Income Database. http://www.wid.world, 22/03/2016.

Angell, A., \& Graham, C. (2009). Can Social Sector Reform Make Adjustment Sustainable and Equitable? Lessons from Chile and Venezuela-p. Journal of Latin American Studies, 27(1), 189-219. DOI:10.1017/S0022216X0001021X

Armendáriz, B., \& Larraín B., F. (2017). The Economics of Contemporary Latin America. Cambridge: MIT Press.

Arnson, C.J, Bergman, M. \& Fairfield, T. (2012) Taxation and equality in Latin America. Woodrow Wilson Center Update on the Americas.

Arze del Granado, F. J., Coady, D., \& Gillingham, R. (2012). The Unequal Benefits of Fuel Subsidies: A Review of Evidence for Developing Countries. World Development, 40(11), 2234-2248. doi:https://doi.org/10.1016/j.worlddev.2012.05.005

Barrientos, A., \& Santibañez, C. (2009). New Forms of Social Assistance and the Evolution of Social Protection in Latin America. Journal of Latin American Studies, 41(1), 1-26. DOI:10.1017/S0022216X08005099

Barro, R. J., \& Sala-i-Martin, X. (2003). Economic Growth. Cambridge: MIT Press.

Baunsgaard, T., \& Keen, M. (2010). Tax revenue and (or?) trade liberalisation. Journal of Public Economics, 94(9-10), 563-577.

Behrendt, C., \& Hagemejer, K. (2009). Can low-income countries afford social security? In P. Townsend (Ed.), Building decent societies: Rethinking the role of social security in development (pp. 99121). New York: Palgrave Macmillan.

Betranou, F., Casalí, P., \& Velasco, J. J. (2019). The Future of Social Protection in Latin America in a Context of Accelerated Changes. In G. Cruz Martinez (Ed.), Welfare and Social Protection in Contemporary Latin America (pp. 215-232). London: Routledge.

Bierbaum, M., Oppel, A., Tromp, S., \& Cichon, M. (2016). A Social Protection Floor Index: Monitoring National Social Protection Policy Implementation. Maastricht Graduate School of Governance/UNU-MERIT discussion paper, Friedrich Ebert Foundation, Washington, DC.

Borgonovi, E., \& Compagni, A. (2013). Sustaining Universal Health Coverage: The Interaction of Social, Political, and Economic Sustainability. Value in Health, 16(1, Supplement), S34-S38. doi:https://doi.org/10.1016/j.jval.2012.10.006

Breisinger, C., Engelke, W., \& Ecker, O. (2012). Leveraging Fuel Subsidy Reform for Transition in Yemen. Sustainability, 4(11), 2862-2887.

Brown, C., Ravallion, M., \& van de Walle, D. (2018). A poor means test? Econometric targeting in Africa. $\begin{array}{llll}\text { Journal of Development } & \text { Economics, } & 134, & 124 .\end{array}$ doi:https://doi.org/10.1016/j.jdeveco.2018.05.004

Buchanan, R.; Musgrave, R. 1999. Public finance and public choice: Two contrasting visions of the state. Cambridge: MIT Press.

Bukuluki, P., and Watson, C. (2012). Transforming cash transfers: beneficiary and Community Perspectives on the Senior Citizen Grant (SCG) in Uganda. London: Overseas Development Institute.

CAIC. (2008). Final report of the Integral auditing of the Ecuadorian Debt. Quito: http://www.auditoriadeuda.org.ec/images/stories/documentos/Libro CAIC English.pdf.zip.

Cardoso, F. H., \& Faletto, E. (1998). Dependencia y Desarrollo en America Latina: Seleccion Ciencuenta años del pensamiento de la CEPAL: textos seleccionados (Vol. 2, pp. 475-499). Santiago de Chile: Fondo de Cultura Economica/CEPAL.

Cecchini, S., Filgueira, F., Martínez, R., \& Rossel, C. (2015). Towards universal social protection: Latin American pathways and policy tools. Santiago de Chile: ECLAC, United Nations.

CEDLAS, \& World Bank. (2016). Socio-Economic Database for Latin America and the Caribbean (version May 2016). http://sedlac.econo.unlp.edu.ar/eng/.

CEDLAS, \& World Bank. (2020). Socio-Economic Database for Latin America and the Caribbean (version June 2020). http://sedlac.econo.unlp.edu.ar/eng/.

Chatzistefanou, A., \& Kitidi, K. (Writers). (2011). Debtocracy.

Cichon, M. (2018). Hardly Anyone Is Too Poor to Share. Finance \& Development, 55(4), 14-15.

Cichon, M., \& Hagemejer, K. (2007). Changing the development policy paradigm: Investing in Social security floor for all. International Social Security Review, 60(2-3), 169-196. doi:10.1111/j.1468246X.2007.00275.x

Clements, B., Coady, D., \& Piotrowski, J. (2010). Oil subsidies: costly and rising: reducing subsidies worldwide can bring substantial environmental benefits and create much-needed fiscal space.(PICTURE THIS). Finance \& Development, 47(2), 42. 
Coady, D., Parry, I., Sears, L., \& Shang, B. (2015). How Large Are Global Energy Subsidies? IMF Working Paper, 15(105), 1-42.

5 Cowan, S. (2017) Universal Basic Income: Unworkable and Unaffordable. Policy, 33 (4), pp. 14-20.

Cruz-Martinez, G., 2015. Análisis Multidimensional del Estado de bienestar emergente y la pobreza en América Latina y el Caribe: Puerto Rico como estudio de caso, Madrid: Universidad Complutense de Madrid. http://eprints.ucm.es/30004/.

Cruz-Martinez, G., 2016, Universal Targeting Assumptions of Efficiency and Affordability. Pension Watch Briefing Series, HelpAge International, 15. http://www.helpage.org/ download/57d132ef8f8f9.

Cruz-Martinez, G., 2018, 'Revenue-generating potential of taxation for older-age social pensions', Ageing International, Vol. 43, No. 4, pp. 415-437. doi:10.1007/s12126-017-9298-2.

Cruz-Martínez, G., 2017, 'Welfare state development, individual deprivations and income inequality: A cross-country analysis in Latin America and the Caribbean', Social Indicators Research, Vol. 134, No. 3, pp. 955-979. doi:10.1007/s11205-016-1465-4. Forum for Development Studies 25

Cruz-Martínez, G., 2019, 'Older-age social pensions and poverty: Revisiting assumptions on targeting and universalism', Poverty \& Public Policy, Vol. 11, No. 1-2, pp. 31-56. doi:10.1002/pop4.v11.1-2.

Cruz-Martínez, G., 2020, 'Rethinking universalism: Older-age international migrants and social pensions in Latin America and the Caribbean', Global Social Policy, Vol. 20, No. 1, pp. 39-59. doi: $10.1177 / 1468018119873267$.

Cruz-Martínez, G., L. Vargas Faulbaum and R. Velázquez Leyer, 2021, 'Social security and pension systems: The deep stratification of Latin American societies', in Sátyro Natália, del Pino Eloísa and Midaglia Carmen eds, Latin American Social Policy Developments in the Twenty First Century, London: Palgrave, pp.163-194.

Desai, R. M. (2017). Rethinking the universalism versus targeting debate.

Dethier, J.-J., Pestieau, P., \& Ali, R. (2010). Universal Minimum Old Age Pensions: Impact on Poverty and Fiscal Cost in 18 Latin American Countries. World Bank Policy Research Working Paper, 5292, $1-44$.

Devereux, S. (2001). Livelihood Insecurity and Social Protection: A Re-emerging Issue in Rural Development. Development Policy Review, 19(4), 507-519. doi:10.1111/1467-7679.00148

Devereux, S., Masset, E., Sabates-Wheeler, R., Samson, M., te Lintelo, D., \& Rivas, A. (2015). Evaluating the Targeting Effectiveness of Social Transfers: A Literature Review. Institute for Development Studies Working Paper, 460.

Di Bella, G., Norton, L., Ntamatungiro, J., Ogawa, S., Samake, I., \& Santoro, M. (2015). Energy Subsidies in Latin America and the Caribbean: Stocktaking and Policy Challenges. IMF Working Paper, 15(30), 1-79.

Durán-Valverde, F. (2014). Uruguay. Monotax: Promoting formalisation and protection of independent workers. SPF brief, 2: ILO. Retrieved from http://www.socialprotection.org/gimi/gess/ShowRessource. action?ressource.ressourceId=48020.

Durán-Valverde, F. \& Pacheco, J.F. (2012) Fiscal space and the extension of social protection: Lessons learnt from developing countries. Extension of Social Security ESS Paper No. 33. Geneva: ILO. Retrieved from: http://www.ilo.org/gimi/gess/RessFileDownload.do?ressourceId=34168

ECLAC. (2020). Social Pensions: Non-contributory social protection programmes in Latin America and the Caribbean database: Social Development Division: http://dds.cepal.org/bdps/en/.

Engen, E., \& Skinner, J. (1996). Taxation and Economic Growth. National Tax Journal, 49(4), 617-642.

Feldstein, M. (1995). Effect of Marginal Tax Rates on Taxable Income: A Panel Study of the 1986 Tax Reform Act. Journal of Political Economy, 103(3), 551-572.

Fernández Arias, M. E. (2003). La agricultura costarricense ante la globalización : las nuevas reglas del comercio internacional y su impacto en el agro. San Jose: Editorial Universidad de Costa Rica / CLACSO.

Fischer, A.M. (2020), The Dark Sides of Social Policy: From Neoliberalism to Resurgent Right-wing Populism. Development and Change, 51: 371-397. https://doi.org/10.1111/dech.12577

Fricke, H., \& Süssmuth, B. (2014). Growth and Volatility of Tax Revenues in Latin America. World Development, 54, 114-138. doi:http://dx.doi.org/10.1016/j.worlddev.2013.07.007

Gale, W. G. (2017, June 13). What the Kansas tax cut about-face means. Brookings.

Gale, W. G., Krupkin, A., \& Rueben, K. (2015). The relationship between taxes and growth at the state level: New evidence. National Tax Journal, 68(4), 919-941. doi:http://dx.doi.org/10.17310/ntj.2015.4.02

Garfinkle, N. (2005). Supply-side vs demand-side tax cuts and U.S. economic growth, 1951-2004. Critical Review, 17(3-4), 427-448. doi:10.1080/08913810508443647 
Greenstein, R. (2019) Commentary: Universal Basic Income May Sound Attractive But, If It Occurred, Would Likelier Increase Poverty Than Reduce It. Policy Futures. Washington D.C.: Center on Budget and Policy Priorities. Retrieved from: https://www.cbpp.org/research/poverty-andopportunity/commentary-universal-basic-income-may-sound-attractive-but-if-it

Gugusgvili, D. \& Hirsh, D. (2014) Means-testing or Universalismo: What strategies best address poverty? Leicestershire: Loughborough University.

Guven, M.U., \& Leite, P.G. (2016) Benefits and Costs of Social Pensions in Sub-Saharan Africa. Social Protection \& Labor Discussion Paper, No. 1607. World Bank.

Hailu, A., Eregata, G.T., Stenberg, K., \& Norheim, O.F. (2021). Is Universal Health Coverage Affordable? Estimated Costs and Fiscal Space Analysis for the Ethiopian Essential Health Services Package. Health Systems and Reform, 7(1). DOI: 10.1080/23288604.2020.1870061

Hagen-Zanker, J. and McCord, A. (2013), The Affordability of Social Protection in the Light of International Spending Commitments. Development Policy Review, 31: 397418. https://doi.org/10.1111/dpr.12012

Heimo, L. (2019). Domestication of Global Policy Norms: Problematisation of the Conditional Cash Transfer Narrative. In G. Cruz Martinez (Ed.), Welfare and Social Protection in Contemporary Latin America (pp. 134-153). London: Routledge.

Heller, P. (2005). Back to Basics. Fiscal Space: What it is and how to get it. Finance and Development, $42(2)$.

HelpAge International. (2015). Pension-Watch Database. http://www.pensionwatch.net/download/55129fc5749ec.

Hisali, E. (2012). Trade policy reform and international trade tax revenue in Uganda. Economic Modelling, 29(6), 2144-2154. doi:http://dx.doi.org/10.1016/j.econmod.2012.06.033

Hujo, K., \& McClanahan, S. (2009). Financing Social Policy: Mobilizing Resources for Social Development. London: Palgrave Macmillan.

Hungerford, T. L. (2012). Taxes and the Economy: An Economic Analysis of the Top Tax Rates Since 1945. CRS Report for Congress(R42729), 1-20.

ILO (2015) Affordability. Social protection platform. Geneve. Retrieved from: https://www.socialprotection.org/gimi/ShowTheme.action?id=2526

International Energy Agency. (2017). International Energy Statistics. https://www.eia.gov/.

Jouste, M. \& Rattenhuber, P. (2018) A role for universal pension? Simulating universal pensions in Ecuador, Ghana, Tanzania and South Africa. Wider Working Paper 2018/23. https://doi.org/10.35188/UNU-WIDER/2018/465-0

Jubilee Debt Campaign. (2017). JDC Debt Map. Database retrieved from http://jubileedebt.org.uk/wpcontent/uploads/2016/08/JDC-Debt-Map-2015-Data-to-download.xlsx.

Kidd, S., \& Athias, D. (2019). Hit and Miss: An assessment of targeting effectiveness in social protection. Church of Sweden, Development Pathways. Retrieved from https://www.developmentpathways.co.uk/wp-content/uploads/2019/03/Hit-and-MissMarch13.pdf.

Kidd, S., \& Wylde, E. (2011). Targeting the Poorest: An assessment of the proxy means test methodology. Canberra: Australian Government AusAID.

Knox-Vydmanov, C. (2011). The price of income security in older age: Cost of a universal pension in 50 low and middle-income countries. Pension watch briefing series 2, HelpAge International.

Koreh, M. (2017). The Political Economy of Social Insurance: Towards a Fiscal-Centred Framework. Social Policy \& Administration, 51(1), 114-132. doi:10.1111/spol.12187

Laenen, T., \& Gugushvili, D. (2020). Are universal welfare policies really more popular than selective ones? A critical discussion of empirical research. SPSW Working Paper No. CeSO/SPSW/202002. Leuven: Centre for Sociological Research, KU Leuven

Li, M., \& Walker, R. (2016). Targeting Social Assistance: Dibao and Institutional Alienation in Rural China. Social Policy \& Administration, n/a-n/a. doi:10.1111/spol.12261

Lopes da Dilva, D., Tian, N., Marksteiner, A. (2021). Trends in World Military Expenditure 2020. SIPRI Fact Sheet, April, 1-12: https://www.sipri.org/sites/default/files/2021-04/fs 2104_milex_0.pdf.

Macías Vázquez, A. (2008). La reestructuración de la deuda soberana: Multilateralismo, acción colectiva y canje. Problemas del Desarrollo, 39(155), 53-76.

Mahon, J. (2012). Tax Incidence and Tax Reforms in Latin America. Woodrow Wilson Center Update on the Americas.

Martinez-Franzoni, J., \& Sanchez-Ancochea, D. (2016). The Quest for Universal Social Policy in the South: Actors, Ideas and Architectures. Cambridge: Cambridge University Press.

Mason, P. (2016). Postcapitalism: A Guide to Our Future. United Kingdom: Penguin Random House. 
Midgley, J. (2012). Social Protection and Social Policy: Key Issues and Debates. Journal of Policy Practice, 11(1-2), 8-24. doi:10.1080/15588742.2012.624061

Migdalia, C., Ordoñez, G., \& Valencia, E. (2018). Politicas sociales en América Latina en los inicios del siglo XXI: innovaciones,

inercias y retrocesos. Buenos Aires: Clacso, El Colegio de la Frontera Norte.

Ministerio de Hacienda de Costa Rica. (2015). Presupuesto de la República 2015: Ley 9289. http://www.hacienda.go.cr/contenido/13087-ley-de-presupuesto-de-la-republica-2015.

Mkandawire, T. (2005). Targeting and Universalism in Poverty Reduction. Social Policy and Development Programme 23, , United Nations Research Institute for Social Development.

Müller, K. (2009). Contested universalism: from Bonosol to Renta Dignidad in Bolivia. International Journal of Social Welfare, 18(2), 163-172. doi:10.1111/j.1468-2397.2008.00579.x

Niedzwiecki, S. (2018). Uneven Social Policies: The Politics of Subnational Variation in Latin America. Cambridge: Cambridge University Press.

OECD. (2014). The OECD Economic Outlook: Sources and Methods. https://stats.oecd.org/glossary/detail.asp?ID=628.

Ortiz, I., Cummins, M., \& Karunanethy, K. (2015). Fiscal Space for Social Protection. Options to Expand Social Investments in 187 Countries. Extension of Social Security Working Paper, 48, ILO.

Ortiz, I., Cummins, M., Karunanethy, K. (2017a) Fiscal space for social protection: Options to expand social investments in 187 countries. Geneva, ILO; New York, UNICEF and UNWOMEN.

Ortiz, I., Durán-Valverde, F., Pal, K., Behrendt, C., Acuña-Ulate, A. (2017b) Universal Social Protection Floors: Costing Estimates and Affordability in 57 Lower Income Countries. ESS Working Paper no. 58. Geneva: ILO.

Pal, K., Behrendt, C., Leger, F., Cichon, M., \& Hagemejer, K. (2005). Can Low Income Countries Afford Basic Social Protection? First Results of a Modelling Exercise. International Labour Office, Social Security Department, Issues in Social Protection, 13, Available at SSRN: https://ssrn.com/abstract $=807366$.

Pan American Health Organization (2020) Fiscal Space for Health in Latin America and the Caribbean. Washington, D.C.

Paul Dunne, J., Perlo-Freeman, S., \& Soydan, A. (2004). Military expenditure and debt in South America. Defence and Peace Economics, 15(2), 173-187. doi:10.1080/1024269032000110540

Piketty, T., Saez, E., \& Stantcheva, S. (2011a). Optimal taxation of Top Labor Incomes: A Tale of Three Elasticities. CEPR Discussion Paper, 8675(December).

Piketty, T., Saez, E., \& Stantcheva, S. (2011b). Taxing the 1\%: Why the top tax rate could be over $80 \%$. CEPR's Policy Portal, http://www.voxeu.org/article/taxing-1-why-top-tax-rate-could-be-over$80 \# f n 1$.

Prebisch, R. (1986). El desarrollo economico de la America Latina y algunos de sus principales problemas. Desarrollo Economico, 26(103), 479-502. doi:10.2307/3466824

Pribble, J. (2013). Welfare and Party Politics in Latin America. Cambridge: Cambridge University Press.

Prince, M. J. (2001). How Social is Social Policy? Fiscal and Market Discourse in North American Welfare States. Social Policy \& Administration, 35(1), 2-13. doi:10.1111/1467-9515.00216

Puerto Rico Commission for the Comprehensive Audit of the Public Credit. (2016). Pre-Audit Survey Report. $\quad$ http://www.80grados.net/wp-content/uploads/2016/06/Interim-Report-Final-withExhibits-1-1-1.pdf.

ReFund America Project. (2016). Puerto Rico's Payday Loans. https://www.scribd.com/doc/317074793/Puerto-Rico-s-Payday-Loans.

Reynolds, A. (2019) Optimal top tax rates: a review and critique. CATO Journal, 39(3), pp. 635-665. DOI: 10.36009/CJ.39.3.8

Roser, M. and E. Ortiz-Ozrpina, 2013, 'Income inequality', Our World In Data. https:// ourworldindata.org/income-inequality

Sandberg, J. (2016). Between Poor Relief and Human Capital Investments - Paradoxes in Hybrid Social Assistance. Social Policy \& Administration, 50(3), 316-335. doi:10.1111/spol.12111

Seekings, J. (2017) Affordability and the political economy of social protection in contemporary Africa. Wider Working Paper, No. 2017/43. The United Nations University World Institute for Development Economics Research (UNU-WIDER), Helsinki, http://dx.doi.org/10.35188/UNUWIDER/2017/267-0

SIPRI. (2017). SIPRI Military Expenditure Database. Stockholm International Peace Research Institute: https://www.sipri.org/databases/milex.

Smith, S. (2015). Taxation: A Very Short Introduction. Oxford: Oxford University Press. 
Social Security Administration. (2016). Social Security Programs Throughout the World: The Americas, 2015. https://www.ssa.gov/policy/docs/progdesc/ssptw/20142015/americas/ssptw15americas.pdf.

Sojo, A. (2017). Protección social en América Latina: la desigualdad en el banquillo. Santiago de Chile: CEPAL, Naciones Unidas.

Sottoli, S. (2000): La política social en América Latina bajo el signo de la economía de Mercado y la democracia. Instituto de Investigaciones Sociales. Revista Mexicana de Sociología, 62 (4), pp. 4365 .

Stone, D. A. (1989). Causal Stories and the Formation of Policy Agendas. Political Science Quarterly, 104(2), 281-300. doi:10.2307/2151585

Syed, M., Papi, L., Palomba, G., Corbacho, A., Mumssen, C., John, J., . . Danninger, S. (2016). Assessing Fiscal Space - An Initial Consistent Set of Considerations. Washington DC: International Monetary Fund: http://www.imf.org/en/Publications/Policy-Papers/Issues/2017/01/13/pp5080Assessing-Fiscal-Space-An-Initial-Consistent-Set-of-Considerations.

Taşıran, A. C., \& Elveren, A. Y. (2017). Soft Modelling of Military Expenditures, Inequality and Profits. Paper presented at the American Economic Association Annual Meeting, Chicago. https://www.aeaweb.org/conference/2017/preliminary/1747? page $=2 \&$ per-page $=50$

Töngür, Ü., \& Elveren, A. Y. (2016). The nexus of economic growth, military expenditures, and income inequality. Quality \& Quantity, 1-22. doi:10.1007/s11135-016-0368-4

Toussaint, E. (2012) You can cancel the debt/Interviewer: D. Papageorgiou. Crash, Committee for the Abolition of Illegitimate Debt: http://www.cadtm.org/Eric-Toussaint-You-can-cancel-the.

UNCTAD. (2012). Principles on Promoting Responsible Sovereign Lending and Borrowing. United Nations: http://unctad.org/en/PublicationsLibrary/gdsddf2012misc1 en.pdf.

UNPD. (2019). World Population Prospects: The 2019 Revision. Percentage of Total Population by Broad

Age Groups. https://population.un.org/wpp/Download/Standard/Population/

Verguet, S., Hailu, A., Eregata, G.T., Memirie, S.T., Johansson, K.A. (2021) Toward universal health coverage in the post-COVID-19 era. Nature Medicine, 27 (3), pp. 380-387.

Williamson, J. (1990). What Washington Means by Policy Reform. In J. Williamson (Ed.), Latin American adjustment: How Much Has Happened? Washington DC: Institute for International Economics.

Willmore, L. (2007). Universal pensions for developing countries. World Development, 35(1), $24-51$.

Wolff, J. (2013). Towards Post-Liberal Democracy in Latin America? A Conceptual Framework Applied to Bolivia. Journal of Latin American Studies, 45(1), 31-59. doi:10.1017/S0022216X12000843

World Bank (2012b). Managing Risk, Promoting Growth: Developing Systems for Social Protection in Africa. Washington, DC: World Bank.

World Bank. (2020). World Development Indicators. Washington D.C.: http://data.worldbank.org/products/wdi.

WTO. (2016). World Tariff Profiles. Summary Tables. https://www.wto.org/english/tratop e/tariffs e/tariff data e.htm. 